\title{
ACTIONS FOR THE ENHANCEMENT OF HERITAGE. THE CASE OF THE TOWN WALLS OF MORELLA (CASTELLÓN, SPAIN)
}

\author{
S. Portela i Valls ${ }^{1, *}$, M.J. Viñals ${ }^{2}$, G. Muñoz Cosme ${ }^{2}$ \\ ${ }^{1}$ Universitat Politècnica de València, Valencia, Spain - saporiv@ arq.upv.es, \\ ${ }^{2}$ Research Centre PEGASO, Universitat Politècnica de València, Valencia, Spain - (mvinals, gmcosme)@upv.es
}

Commission II - WG II/8

KEY WORDS: City Walls, Conservation, Defence Heritage, Medieval Architecture, Morella (Spain), Public Visit

\begin{abstract}
:
Morella is an archetypical medieval town that is home to many heritage buildings, protected by fortified walls and crowned by an imposing castle. Located in a mountainous area, this town is one of only four examples in the Valencian Region (Spain) that retain the entire defence perimeter. This defence heritage has been decisive not only in shaping the urban layout of the town, but also in the local lifestyle and traditions of the place: living inside the walls means being protected from the weather, but also inhabiting a limited environment and having social and cultural connotations. The process of enhancing the value of heritage buildings involves studying, analysing and understanding the elements they are made up of with the aim of proposing new uses based on their significance, their characteristics, the environment and social needs. To address this objective, the present work has carried out an architectural analysis of each of the towers and gates of the town walls, which has made it possible to study their characteristics and detect the potential for the interpretation of the heritage buildings in each section. The result is the 'Walls Walking Tour', a proposal for a public visit that divides the walled perimeter of Morella into five thematic areas that each offers different types of routes, activities and relationships with the environment. In short, this initiative contributes to the enhancement and cultural diffusion of Morella's defence heritage, and brings buildings and their history closer both to the local population and to visitors.
\end{abstract}

\section{INTRODUCTION}

The study of the history, architecture and urban layout of our towns and cities allows us to understand their evolution until the present day. Fortified walls are a key element in the development of any settlement and have determined not only their configuration as towns, but also the lifestyle of the local society and its traditions.

Fortified walls played an essential role in the defence and protection of the towns and cities that appeared in medieval times. However, the wars in subsequent centuries and the expansion of the urban areas have caused serious damage to this outstanding architectural legacy. Likewise, the fact that they fell into disuse, together with the lack of maintenance, have accelerated the process of degradation of the walls and the materials that they are made up of.

This situation highlights an urgent need for intervention on the walls, both on the specific scale of each of the different constituent architectural elements and on a global scale involving the town in relation to its immediate surroundings. However, we encounter a number of problems when addressing this type of undertaking in urban areas. The walls are an indissoluble part of the town that they protect and have a high historical, scenic and environmental value. Their survival is part of our historical memory, a collective memory that we have the responsibility to pass on to future generations in the best possible conditions. With this in mind, there are two perspectives from which to approach an architectural restoration intervention today: "Conserve to use" or "Conserve to contemplate" (Javier Gallego, 1996).
In order to understand the functioning of medieval historical centres in relation to the urban morphology, it is essential to know the original layout of the walls. Therefore, safeguarding and conserving this defence heritage does not only seek to recover and to contemplate forms or volumes integrated into the urban landscape, but also to transmit the origin and significance of its architecture.

This paper addresses the study of Morella, a unique medieval urban ensemble with an extensive and significant heritage of high historical and architectural value. Located in a mountainous environment, its strategic geographical location made it the focus of numerous military conflicts over the centuries, and it eventually became the second most important town in the Kingdom of Valencia.

The town itself is inseparable from its rugged landscape, the castle that crowns the rocky crag, and the walls that surround the town, with their corresponding towers and gates, an image that has become the icon of the town. However, it is not only a town that has preserved its heritage over the years - it is also alive and has managed to maintain its most deeply rooted customs and traditions.

\section{BACKGROUND}

During the 19th century, the rapid population growth and the need to improve urban health conditions resulted in an urban sprawl that caused the disappearance of a large part of the walls surrounding many towns and cities. Sections of the walls, towers and gates were then demolished to allow the great avenues to continue, or the structures were reused as dividing walls and even became part of the new constructions. Thus, the town walls were progressively fragmented and lost their continuity, an essential characteristic of this type of heritage asset.

\footnotetext{
* Corresponding author
} 
In some towns, the walls were unexpectedly demolished, as in the case of València in 1865 . The city was suffering from overcrowding and highly unsanitary conditions and it was decided to extend the urban layout towards the south by means of the orderly reticulated arrangement of the "Ensanche" (Taberner, 2010). This phenomenon became widespread throughout Spain and many towns demolished their walls, such as Barcelona in 1854 and San Sebastián in 1864. In this way, with the passage of time, historical remains became part of the urban system of modern cities.

In view of the above-mentioned events, it is clearly of extreme importance to conserve and to restore the defence heritage elements that have survived those demolition processes. Few historical sites of this kind have survived to this day, and even fewer remain harmoniously integrated within their surroundings.

In Spain, there are several examples of conservation work on city walls carried out over the last century, with interventions based on an array of different restoration criteria: Ávila, Tarragona, Montblanc, Barcelona, Girona, Gijón, Buitrago, Alcalá de Henares and Granada are just a few examples.

In this respect, we should highlight the strategy carried out in Catalonia in the second decade of the 20th century in response to the systematic destruction that the defence heritage had suffered in the previous century. This policy involved the cultural institutions promoting a social awareness campaign to recover and restore the city walls.

According to Lacuesta (1996), the primary and secondary cities had already lost a good part of their walls, but the small towns, which were not pressed to expand, had the opportunity to save them. It was the architect Jeroni Martorell (1876-1951), director of the Monument Conservation, Cataloguing and Public Registering Service of the Diputació of Barcelona, who promoted different actions to conserve and safeguard the walled ensembles, such as establishing legal protection for monuments, urban planning projects, restorations and public works.

A paradigm of the conservation of fortified walls in Spain is the case of Ávila, a city that maintains its unique medieval character thanks to the complete conservation of its walls and its conception as a magnificent monumental setting. It is an example of perfect coexistence between the architecture of the historical town and the life and new needs of the contemporary town and its inhabitants.

According to Hernández (1996), the slow growth of the population experienced by Ávila during the 19th century and the high quality of the construction of its walls and defence towers were the factors that made their conservation possible. As a result, in 1985 the town of Ávila was registered on UNESCO's World Heritage List, with the medieval wall and the outside Romanesque churches of San Pedro, San Vicente, San Andrés and San Segundo being expressly cited in the registration ${ }^{1}$.

In the Valencian Region, today there are only four medieval towns that have preserved the entire structure of their walls: Peñíscola, Tabarca, Mascarell and Morella. Due to its particular geographical conditions, as well as the exceptional historical and military importance of the town, we will take the walls of the town of Morella as a case study.

\section{THE CASE OF THE MEDIEVAL TOWN OF MORELLA}

Morella is an archetypical medieval town and one of the bestpreserved urban complexes of its characteristics in the whole of the Iberian Peninsula, as noted by Dalmases and Pitarch (1983). This small town, located in the north of the province of Castellón, has its origins in the castle that crowns the rocky crag known as the "Mola", in a strategic military spot that allowed it to dominate the entire valley (Figure 1).

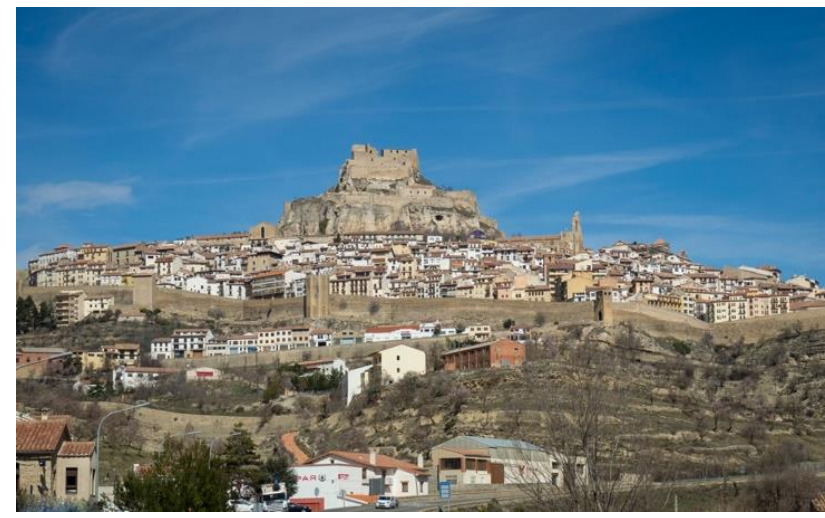

Figure 1. View of the town of Morella (Source: S. Portela, 2018).

The first documented settlements in the area date back to Roman times, in the 2nd century, when work began on the fortification of the castle. As of the year 476, much of Spain was ruled by the Visigoths until the 8th century, when their dominion came to an end with the Arab conquest in 714, and the town was then renamed "Mourelia".

The fortress was built in the 11th century, but it was not until the 13th century, following the Christian reconquest, that the urban morphology of the Morella as we know it today began to take shape. Thus, in 1232, Don Blasco de Alagón took the castle of Morella and, later, King Jaume I "The Conqueror" granted it the Municipal Charter ("Carta Puebla"). Following the Christian conquest, the town began to grow and structure itself outside the castle walls, following the natural slope of the mountain. In 1358, the town responded to the wars of that time by also walling itself off from the front (Dalmases, Pitarch, 1983).

Between the 13th and 15th centuries, Morella underwent the greatest period of splendour in its entire history. During this period its economic, political and cultural power became firmly established and the most notable interventions took place, which made it one of the most outstanding urban centres of the Kingdom of Valencia during the 14th and 15th centuries (Id., 1983).

\subsection{Urban planning and heritage}

Morella has particular conditions that make it a unique case to be enhanced. The town is located in an inland mountainous area, at an altitude of 1,000 metres, where the topographical features condition the urban morphology and the layout of the walls (Figure 2), which have sections running in different directions and a number of towers so as to be able to defend the town adequately from all possible angles. Therefore, we are talking about a unique and highly relevant heritage ensemble, both because of the long history of the town and due to the quality of its defence architecture.

https://whc.unesco.org/es/list/348 (retrieved January 2020) 


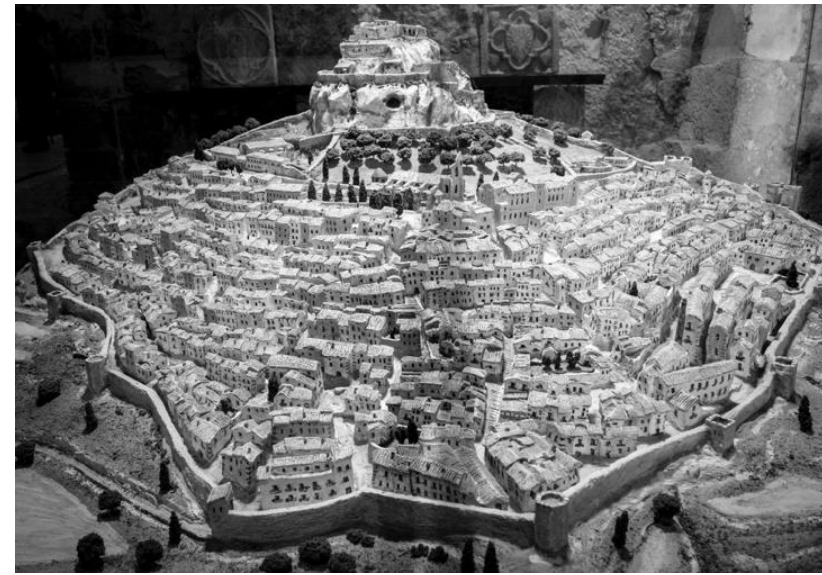

Figure 2. Picture of the urban model of Morella, on display in the Palacio del Gobernador, in the Castle (Source: S. Portela, 2018).

The main historical elements of the town are located inside its walls, such as the Castle, the Archpriestal Church of Santa Maria, the Convent of San Francisco and the churches of Sant Miquel, Sant Joan and San Nicolás. There are also various medieval Gothic palaces, such as the Palau del Consell (now the Town Hall), the Ciurana house, Cardinal Ram, the Piquer house or that of the Marqués de Cruilles, as well as buildings from more recent times such as the Escuelas Pías or the Bullring, all of which are surrounded by the walls and their corresponding towers and gates.

On the other hand, the urban landscape of Morella is intrinsically linked to its topography and history; the town cannot be understood without the figure of the fortress that crowns the crag, or without the sections of the wall that protect the urban fabric and give it an identity. The walls have therefore become the icon that represents the town and even today the life of the people of Morella takes place mostly within the walls, a fact that means this heritage asset plays a fundamental role in local life. Thus, for reasons linked to its lifestyle and to protect itself from the wind and the intense cold of winter, the population prefers to live inside the walls.

In 1931, the Castle and Walls of Morella were declared HistoricArtistic Monuments, which underlines the outstanding role played by the Defence Heritage Assets of Morella.

\subsection{The defence walls: elements and characteristics}

The Defence Heritage of Morella mainly comprises the Castle and the walls, with their corresponding towers and gates. However, the Convent of San Francisco is closely related to the defence of the town against the military occupation that took place during the second half of the 19th century and ended in 1909 , a period in which it was attached to the Castle and served as a military barracks. Today they are directly linked, since the current route that affords access to the Castle actually begins in the Convent building.

The walls of Morella have a total length of 1,800 metres, of which 1,385 metres are sections of the wall and 415 metres are occupied by towers and gates, according to data from the Architect Curator of Morella Castle, Vicente Dualde (2016). Altogether the walls have ten towers (Pantó, Racó, Redona, Font Vella, Asperó, Alòs, Beneito, Fredes, Carraixet and Sant Francesc) and six gates providing access to the town (Nevera, Sant Miquel, Sant Mateu, Forcall, Rei and Estudis), as shown in figure 3.
According to Grau i Montserrat (1986), the first documented record of the construction of the current walls dates from 1276. Since then, numerous documents referring to the contracts of the "wall workers" allow us to date a large part of the construction work of the walls between 1276 and 1481 (Dualde, 2016).

However, other authors claim that the work on the walls began in 1330 and was promoted by King Pere "the Ceremonious" from 1358 onwards, as a result of the wars between Aragon and Castile around the year 1359. The work on the walls was finally completed in 1465 (Dalmases, Pitarch, 1983).

Although all these constructions follow the same constructive typology, each of the towers presents a different morphology and characteristics, depending on the location and its function within the defence structure.

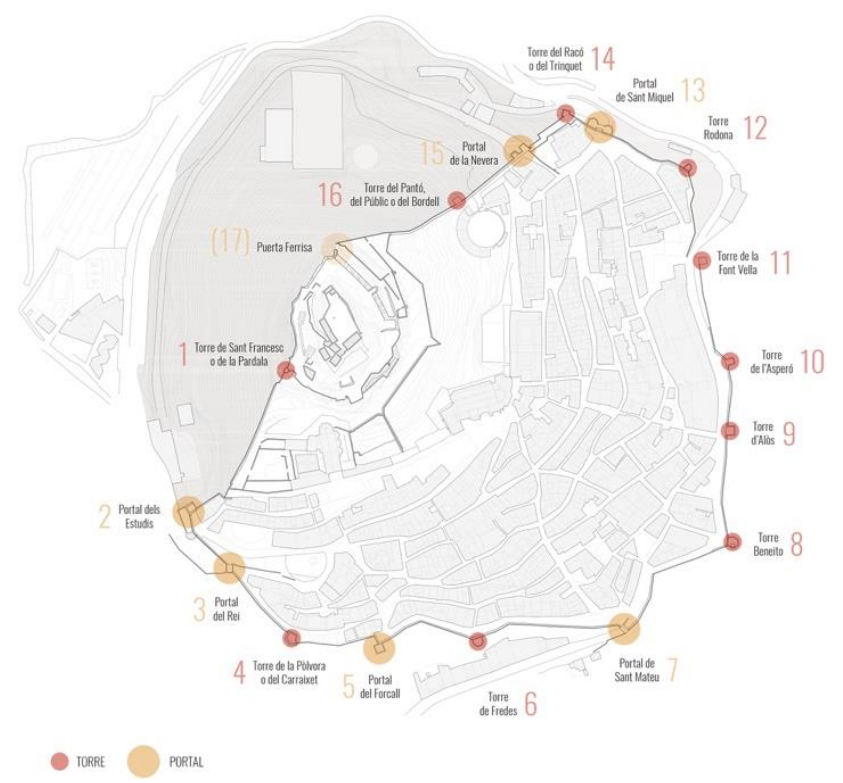

Figure 3. Distribution of the towers and gates of the walls of Morella (Source: Morella Town Council, modified by S. Portela, 2018).

\section{ACTIONS FOR THE ENHANCEMENT OF THE DEFENCE WALLS OF MORELLA}

The preservation and restoration of architectural heritage entails the responsibility of assigning some functionality to the elements, as well as planning their adequate management and maintenance. Consequently, the intervention can be focused on recovering the original use of the building or on opting for other functions that are better adapted to the new needs of the site and society (adaptive re-use).

Defence heritage assets are a type of construction that, in most cases, have lost their original use forever. Therefore, when it is not possible to return to the original use of the asset, it has to be decided whether to "consolidate to contemplate" or "rehabilitate to provide for new uses".

When speaking of new functions, it should be stressed that these will have to bring value to today's society and act as mirrors of the collective memory of the past and its traditional practices. At the same time, it is necessary to ensure it maintains a relationship with the culture of the present and constitutes a source of knowledge and significance for the future. 
In the case of Morella, we are faced with a heritage complex that is complete and of exceptional historical and architectural value. It is also in a good state of conservation, as all the towers and gates have been restored in recent years. Furthermore, the relationship between the walled perimeter and the town is indissoluble, since the latter is perfectly delimited by the walls, life takes place inside them and the natural landscape extends beyond them (Figure 4). On the other hand, along the walls, we find a great variety of towers and gates in terms of their morphology, dimensions and possible uses.

As a result, one of the actions proposed within the framework of the enhancement of Morella's defence heritage is to carry out an interpretive tour along the walls which will allow both residents and visitors to enjoy a route along the entire walled perimeter and will transport them back to their origins. This action fits perfectly into Morella's tourism development strategy.

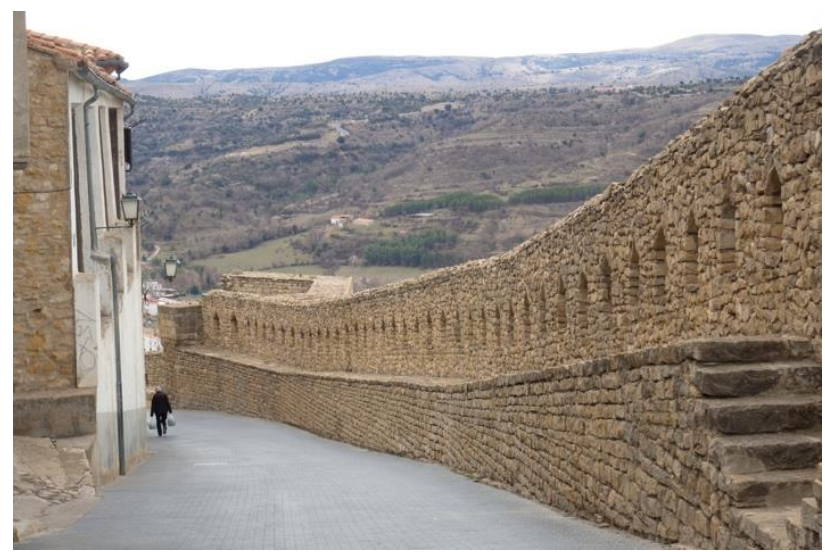

Figure 4. Relationship between the town and the external landscape in the south-western area (Source: S. Portela, 2018).

Various actions are proposed in this project to enhance the value of Morella's walls. One is to create a "Walls Walking Tour" covering all the wall structure and consisting of different sectors, activities and types of visit. Another proposal is to design an interpretive route focused on the defence architecture represented by the north-eastern section of the walls ("Defence Architecture Interpretive Route"). A third action is to set up a specific museum space ("Morella Visitor Centre"), with educational exhibition material and with the support of new technologies, where these matters can be understood in depth (Portela, 2019).

However, prior to the development of a project of these characteristics, it is necessary to stress the importance of consolidating, rehabilitating and carrying out the necessary physical adaptations in the walls, as well as in the towers and gates that require them, in order to ensure the safety of the users in the proposed public visits.

\section{5. "WALLS WALKING TOUR"}

When analysing the formal characteristics of Morella's defence elements, we can see that the layout of the walls and towers is intrinsically linked to the topographical conditions: the Castle stands at the top of the "Mola" crag, while the town faces southeast, so as to make the most of the sunshine.

These particularities are made apparent in the layout of the elements in the walls; thus, the presence of defence towers on the perimeter where the town goes about its business is intensified, while the part facing north-west, which touches the hill, becomes just a section of the wall with few towers. That is, the part which is adjacent to the hill to the north-west, due to being steeper and more inaccessible, requires less architectural protection, while the rest of the perimeter, which does not have such high slopes, needs a greater density of defence elements (Figure 3).

These characteristics are of vital importance when it comes to designing a route along the walls, and even more so when the defence heritage asset was designed, by definition, to be inaccessible from the outside. On the other hand, the purpose that we seek now with the project is to make it available for public visitation.

Of all the walled perimeter, the section between the Portal dels Estudis and the Portal de la Nevera, on the south side, is the one with the smallest variation in elevation, which means a flatter route. Therefore, to avoid walking routes with excessive ups and downs (Figure 5), this will be chosen as the most appropriate perimeter to carry out the public visitation project.

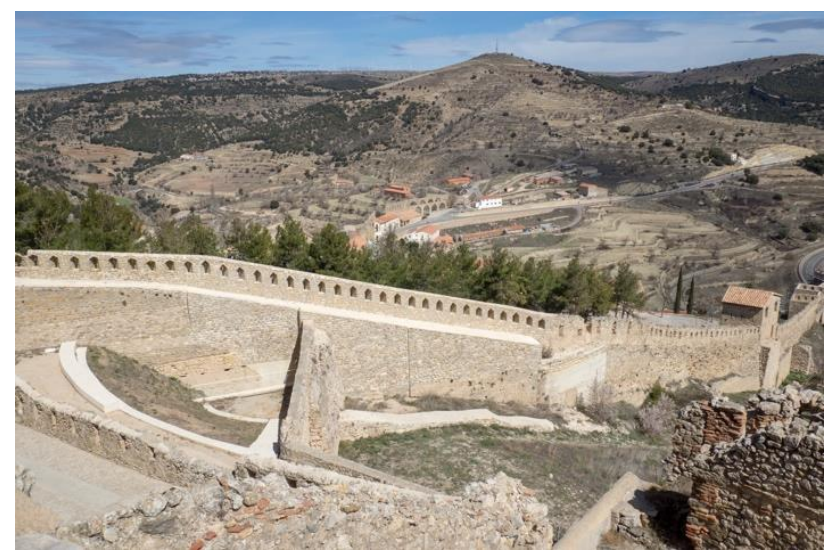

Figure 5. Section of the wall with a steep slope, between the Portal de la Nevera and the Castle (Source: S. Portela, 2018).

The idea of a continuous visit along the more than 1,500 metres of the wall may be too much for most visitors. Hence, the proposal for the "Walls Walking Tour" project is envisaged as an itinerary divided into different thematic sections that provide a variety of attractive contents and experiences, both for the local inhabitants and for visitors.

Specifically, the following five sectors have been defined for public visitation (Figure 6):

- Section I: Urban Planning and Town.

- Section II: Inside/Outside Visit.

- Section III: Landscape and Surroundings.

- Section IV: History of Morella.

- Section V: Defence Architecture.

The "Walls Walking Tour" therefore consists of a route that includes a set of thematic sections that are independent but at the same time complementary. These sections offer different types of visits: free urban walk (sections I, II, III), guided interpretive visits (sections II, IV, V) or free/guided visits to museums (section IV).

The cultural offer is thus adapted to the preferences and needs of each visitor, and varies between walking along the parapet walkway of the walls to freely enjoy the landscape, or having a professional interpreter to know and experience the defence architecture asset and its history. 


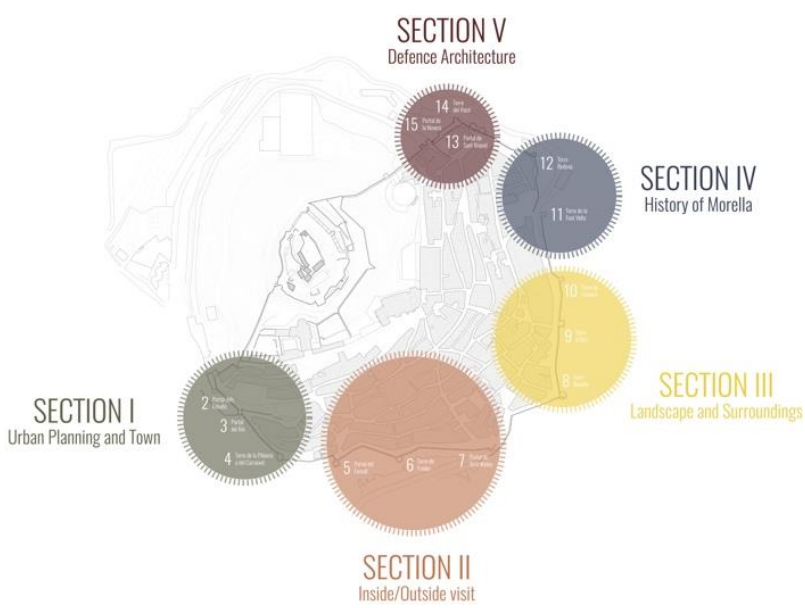

Figure 6. Thematic sections of the "Walls Walking Tour" (Source: S. Portela, 2018).

\subsection{Section I: Urban Planning and Town}

The first section of the "Walls Walking Tour" (Figure 7) includes the Portal dels Estudis, the Portal del Rei and the Torre del Carraixet, and it is designed as a free visit focused on allowing visitors to enjoy the urban environment.

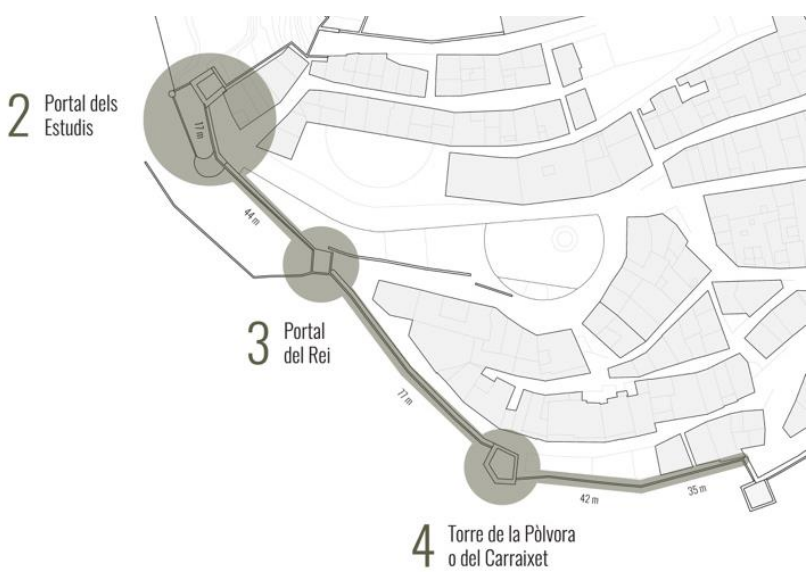

Figure 7. Section I of the "Walls Walking Tour" (Source: Morella Town Council, modified by S. Portela, 2018).

The Portal dels Estudis is a suitable place to start the tour as it is located at one end of the wall; it is an entrance to the town and it is also linked to a square. We would then continue towards the Portal del Rei, which has a viewpoint that forms part of the Plaza dels Estudis itself, and we could cross the tower on the inside and reach the next section of the walls that runs towards the Torre del Carraixet (Figure 8).

The Torre del Carraixet is only partially conserved. It is an appropriate location to observe the interior of the town and thus understand its urban structure. It is also an ideal place for developing urban agricultural projects, creating a kind of a garden, inspired by the old Huerto del Barón that was located at this point in the town. On the other hand, the Portal del Rei is the place where King Jaume I is said to have first entered the town, a fact that endows it with a special historical significance.

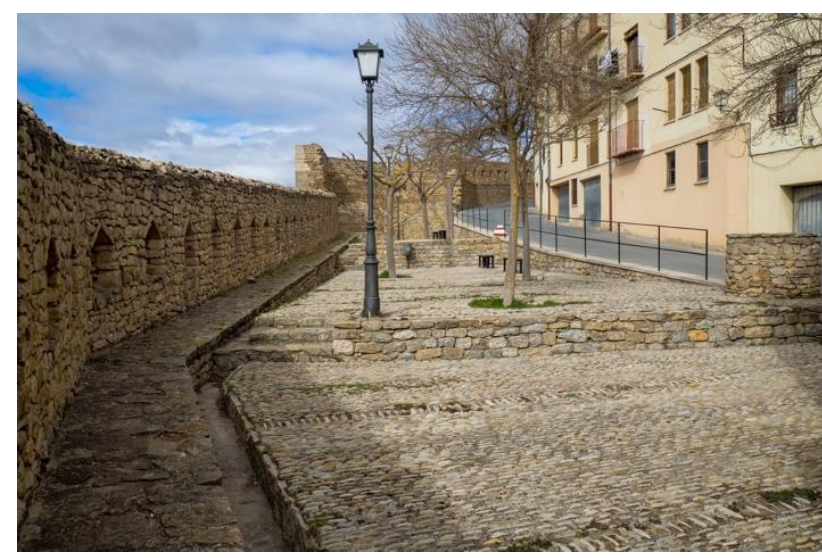

Figure 8. Urban area adjacent to the Torre del Carraixet (Source: S. Portela, 2018).

\subsection{Section II: Inside/Outside Visit}

The next section of the tour (Figure 9) includes the Portal del Forcall, the Torre de Fredes and the Portal de Sant Mateu, and it is the only one that goes outside the town walls, thanks to a pathway that connects the Portal del Forcall to that of Sant Mateu.

The two gates and the tower are fully preserved and their interior offers suitable characteristics for use as conference rooms. Thus, this section of the tour is planned as a free on-demand visit to the buildings, or as spaces available to the residents for different cultural events such as book presentations, lectures, etc.

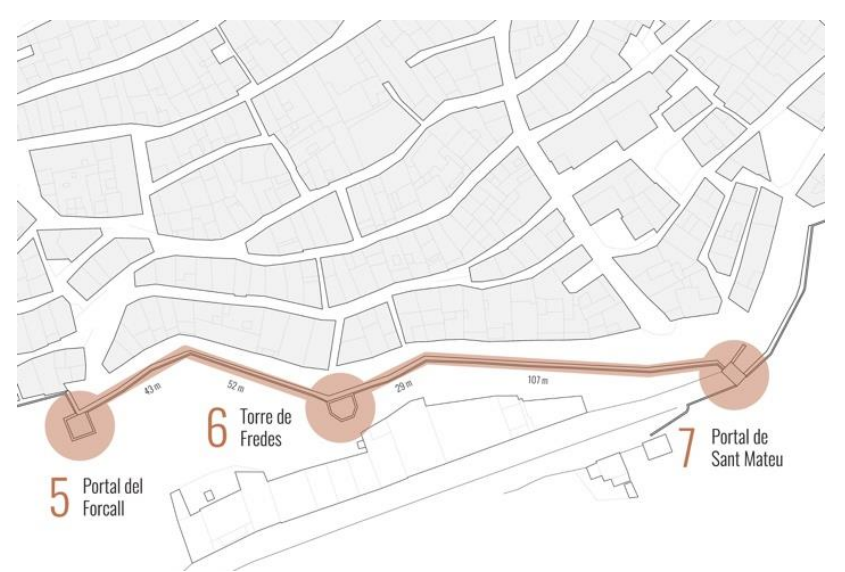

Figure 9. Section II of the "Walls Walking Tour" (Source: Morella Town Council, modified by S. Portela, 2018).

\subsection{Section III: Landscape and Surroundings}

The third section (Figure 10) contains the Torre Beneito, the Torre d'Alòs and the Torre de l'Asperó, and it is the one with the best views of the surrounding landscape. Furthermore, it is located at an intermediate point on the whole "Walls Walking Tour". This fact, together with the spatial characteristics of the towers mentioned above, makes it a suitable area for visitors to stop to rest and take some refreshment. 


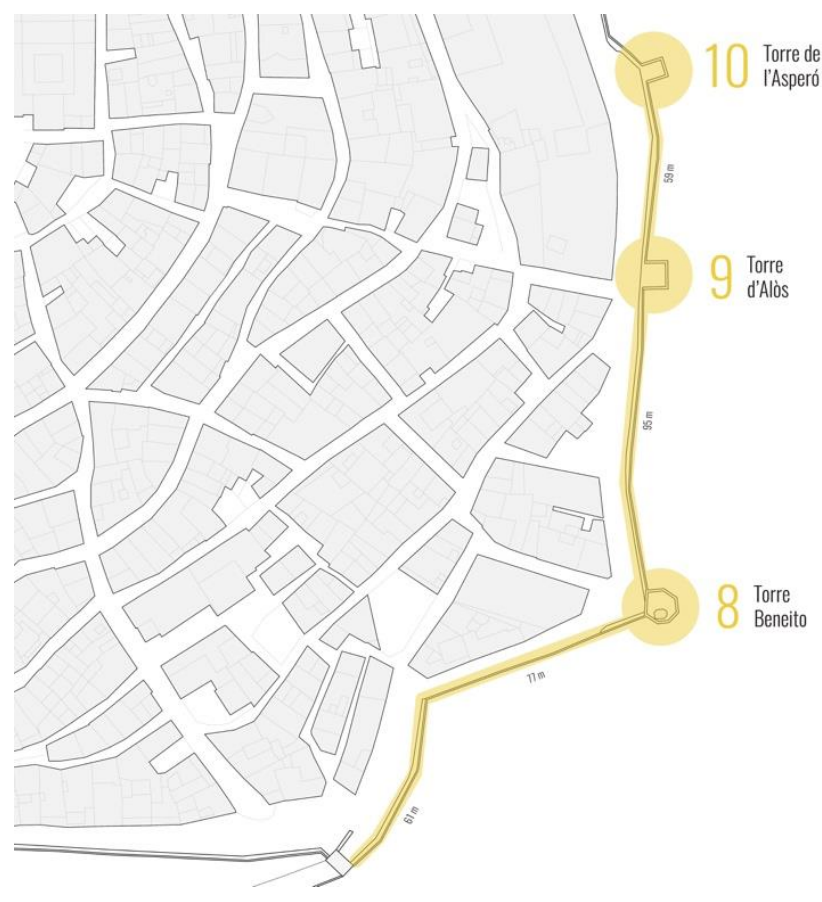

Figure 10. Section III of the "Walls Walking Tour" (Source: Morella Town Council, modified by S. Portela, 2018).

Torre Beneito (Figure 11) has two floors and a flat roof that can be accessed. Its layout and dimensions make it an ideal place to offer the public a food and beverage service. In contrast, the Torre d'Alòs and the Torre de l'Asperó are two of the smallest towers in the whole ensemble and their structures have not survived the passage of time, and so their function would be limited to providing ancillary services.

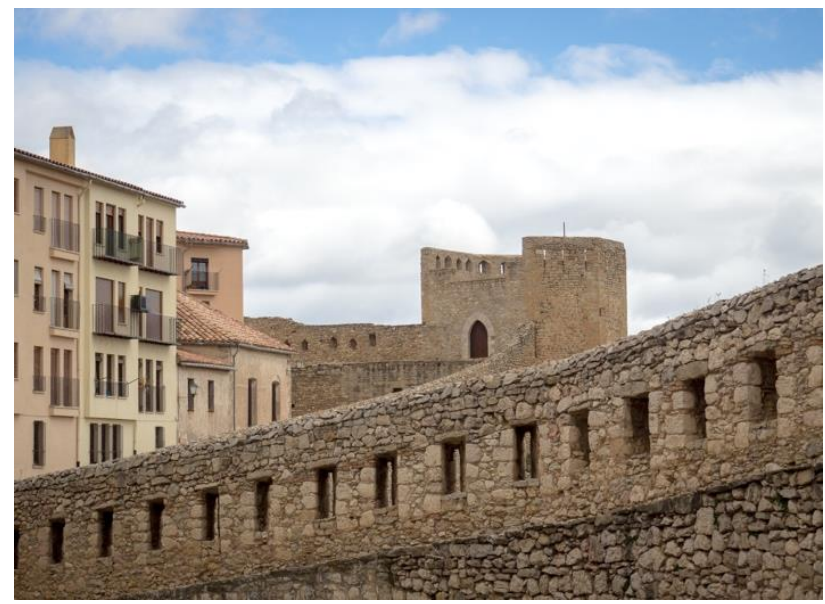

Figure 11. Section of the wall, with Torre Beneito in the background (Source: S. Portela, 2018).

\subsection{Section IV: History of Morella}

The fourth section of the public visit (Figure 12) includes the Torre de la Font Vella and the Torre Redona, two recently restored buildings which have been proposed for use as cultural containers that, thematically, address the history of Morella. In this part of the wall the proposal consists of a guided visit to museums in order to highlight thematic of outstanding importance in the town. Morella needs a cultural space to promote its history.

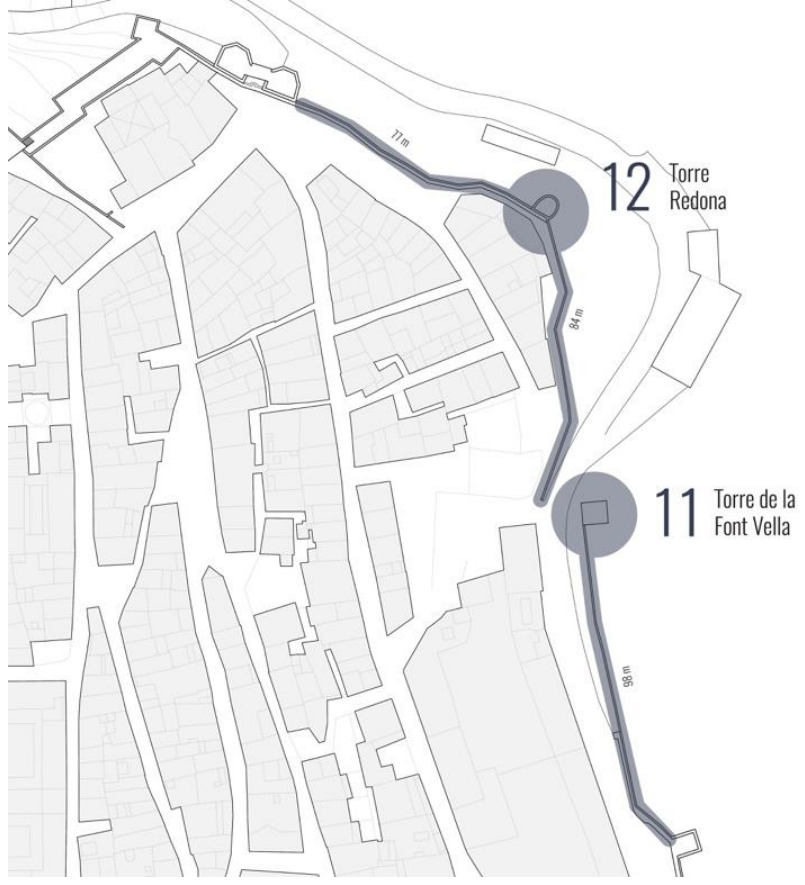

Figure 12. Section IV of the "Walls Walking Tour" (Source: Morella Town Council, modified by S. Portela, 2018).

The Torre de la Font Vella is situated at the end of the tour followed by the aqueduct, next to the fountain of the same name. In medieval times, this element was the town's main cistern, until the early 19th century when the Alameda water tank was built (Dualde, 2016). That is why the rehabilitation project for this tower proposes its use to hold an exhibition related to the topic of water. On the other hand, the proposal for the Torre Redona is to turn it into a museum on the history of the town itself, where the most outstanding historical facts about Morella from its foundation to the present day are highlighted.

It is worth mentioning that in this section we find ourselves before the only fracture in the walls in the whole defence ensemble, due to the fact that in the year 1934 a part of the wall was dismantled to allow the passage of vehicles towards the Portal de Sant Miquel (Dualde, 2016).

\subsection{Section V: Defence Architecture}

Finally, the fifth section of the "Walls Walking Tour" (Figure 13) takes place in the Portal de Sant Miquel, the Torre del Racó and the Portal de la Nevera, and consists in a guided interpretive visit about the defence architecture of Morella.

This section of the walls is of higher architectural quality and contains numerous defence elements, with the presence of the only two gates in the entire wall that have a double tower. This fact grants them a special significance and makes it necessary to enhance their value with a guided interpretive route and a visitor centre.

Despite the importance of Morella's outstanding defence heritage assets, today the town does not have an adequate strategy for enhancing the value of the complex or a museum or visitor centre where this content can be developed. Therefore, within the overall project of the "Walls Walking Tour", an interpretive route is proposed along a limited section (north-eastern section) of the walls that will serve to exemplify the whole structure: the "Defence Architecture Interpretive Route". 


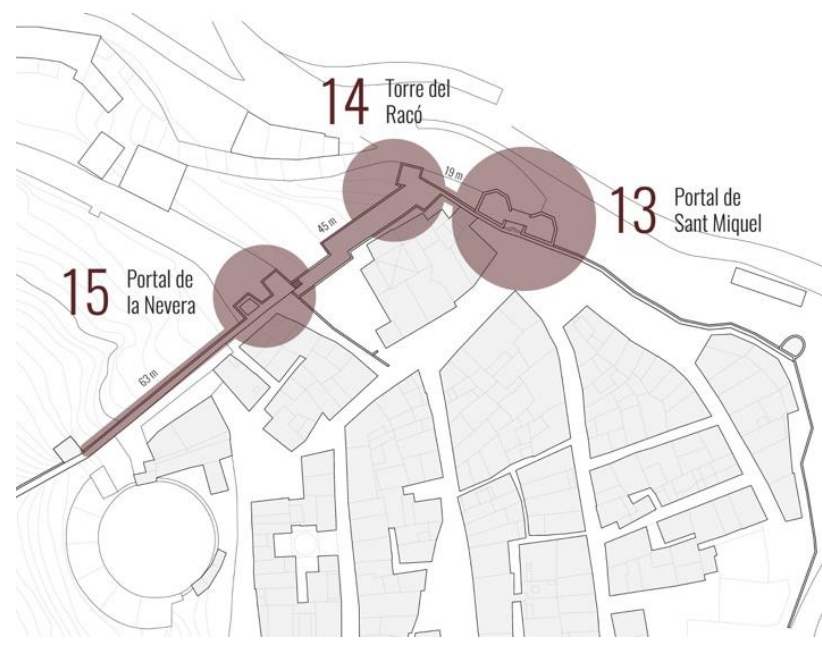

Figure 13. Section V of the "Walls Walking Tour" (Source:

Morella Town Council, modified by S. Portela, 2018).

The public visit that is planned for this section is a circular route that begins in the Portal de la Nevera, goes through one of its towers to the top of the walls, across the roof of the Torre del Racó and continues towards the Portal de Sant Miquel (Figure 14).

This itinerary combines an outdoor visit along the parapet walkway of the wall, which allows visitors to enjoy the exceptional views of the town and the surrounding scenery, and a visit inside the "Morella Visitor Centre" that would be located in the Portal de Sant Miquel, an element of the town's defence ensemble of exceptional significance and architectural quality.
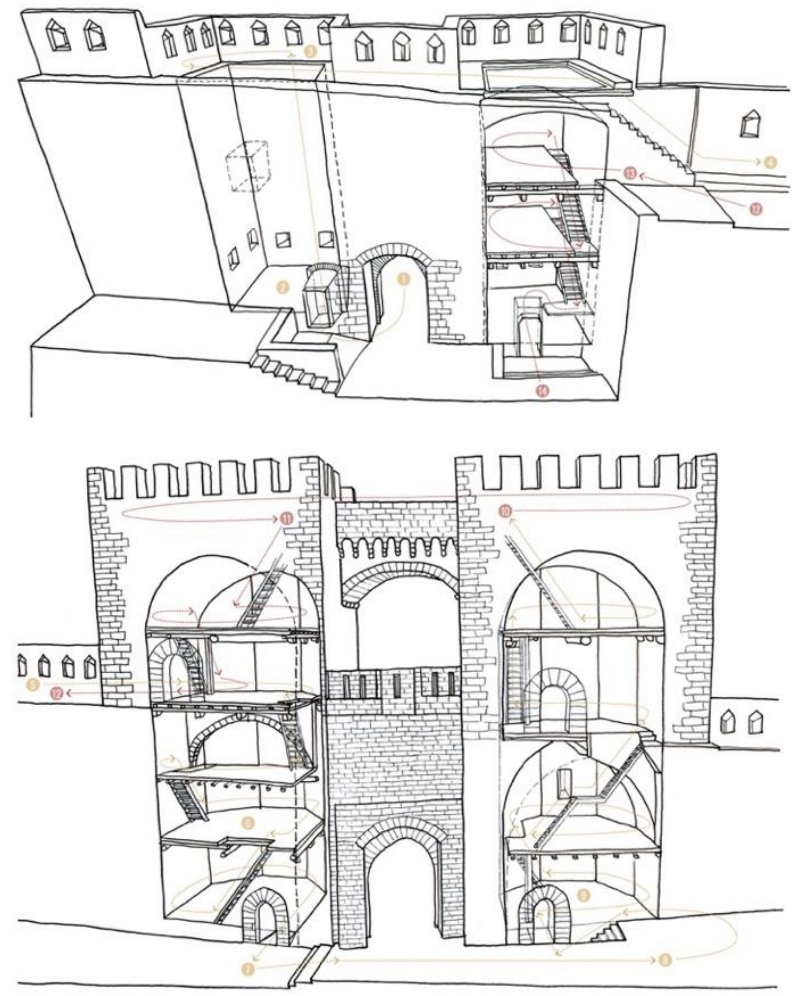

Figure 14. At the top, the touring patterns through the inside of the Portal de la Nevera and, at the bottom, through the Portal de Sant Miquel (Source: S. Portela, 2018).

\section{6 "Museumification" and interpretive programme}

Enhancing the value of a heritage site does not only mean taking steps to ensure its material conservation, creating catalogues, providing legal protection or designing routes, but also paying attention to the intangible aspects linked to the elements, such as their history and the role they played in society in each period of history.

That is why the narration of the content needs to be educational, clear and orderly, but above all it must be carried out through a story that captures the visitor's attention and interest. Accordingly, the content presented in the "Morella Visitor Centre" will be based on a specific topic and theme.

The topic is the general subject on which the exhibition content will be based, i.e. the town's defence ensemble, made up of its walls, towers and gates. On the other hand, the theme, or interpretive message, constitutes the main idea thread through which to approach the topic: in this case, life within a walled town. This concept is essential to attract visitors' attention, since in addition to the purely historical data, the events experienced in a town of these characteristics are an interesting plot for the narrative.

In this way, the Interpretive Programme, in accordance with the proposals of specialists such as Ham (1992), will be based on a series of key questions which, in this case, encourage the visitor to reflect on the significance of the walls and link the historical aspects with the current reality of the place. For example, some of these questions could be:

Why were the walls built and what was the best way to do it? How did the defence system work?

What were the implications of living inside an area surrounded by walls?

What implications can it have today?

The aim of this discourse is for the visitor to get to know some fundamental aspects of Morella's defence complex together with a general idea of how it worked. To facilitate the diffusion of the contents, to increase the attractiveness of the guided tour and to provide intellectual access to some of the contents, the use of the new technologies for heritage such as Virtual Reality and Augmented Reality could be incorporated, especially when the heritage elements are difficult to access.

\section{CONCLUSIONS}

Throughout this work, it has been noted that the historical and architectural significance of the defence ensemble of Morella, the role of the walls as a social element that shaped the town and the uniqueness of the whole complex constitute key elements to understand the evolution and the characteristics of the town and its residents. In any case, all these elements need to be enhanced in order to be transmitted to the public in an adequate manner (Figure 15).

It has been demonstrated that carrying out a proposal to enhance these heritage elements based on the design of a "Walls Walking Tour", a "Defence Architecture Interpretive Route" and a Visitor Centre is technically and conceptually feasible. This initiative arises from a deep study of the history of the town and its architecture, the characteristics of the place and the current social needs. At the same time, it attempts to facilitate knowledge of the history and the society of Morella, as well as to organise the visits, within a framework in which the town's heritage becomes an element that stimulates tourism in the town. 
This project must be included within the development of a comprehensive initiative that includes the intervention tasks (consolidation, restoration and physical adaptation) required to facilitate public usage activities. In addition, given the importance of this heritage asset, a Conservation and Management Plan or Master Plan for the Walls should be drawn up that includes conservation, as has been developed for Ávila (Instituto del Patrimonio Cultural de España, 2018), or for Dublin (Gowen et al., 2004), Drogheda (Gowen et al., 2006), Limerick (Collins et al., 2008) or Hereford (Baker, 2011), amongst others.

As a final reflection, it can be said that Morella has acknowledged the outstanding importance that its defence ensemble has played throughout history, from the origins of the town to the present. It can also be said that it is a unique town in terms of its conditions and lifestyle, with a great capacity to adapt to new times without forgetting its origins, its roots, its traditions and its identity.

In short, the town can retrieve an essential part of its heritage, while helping to expand its cultural offerings and its attractiveness for visitors, thanks to the development of a pioneering project on public visitation to medieval walls. This action will also have a positive impact on its economic development. Discovering Morella and its walls will be, from now on, a new way to delve into its exciting history.

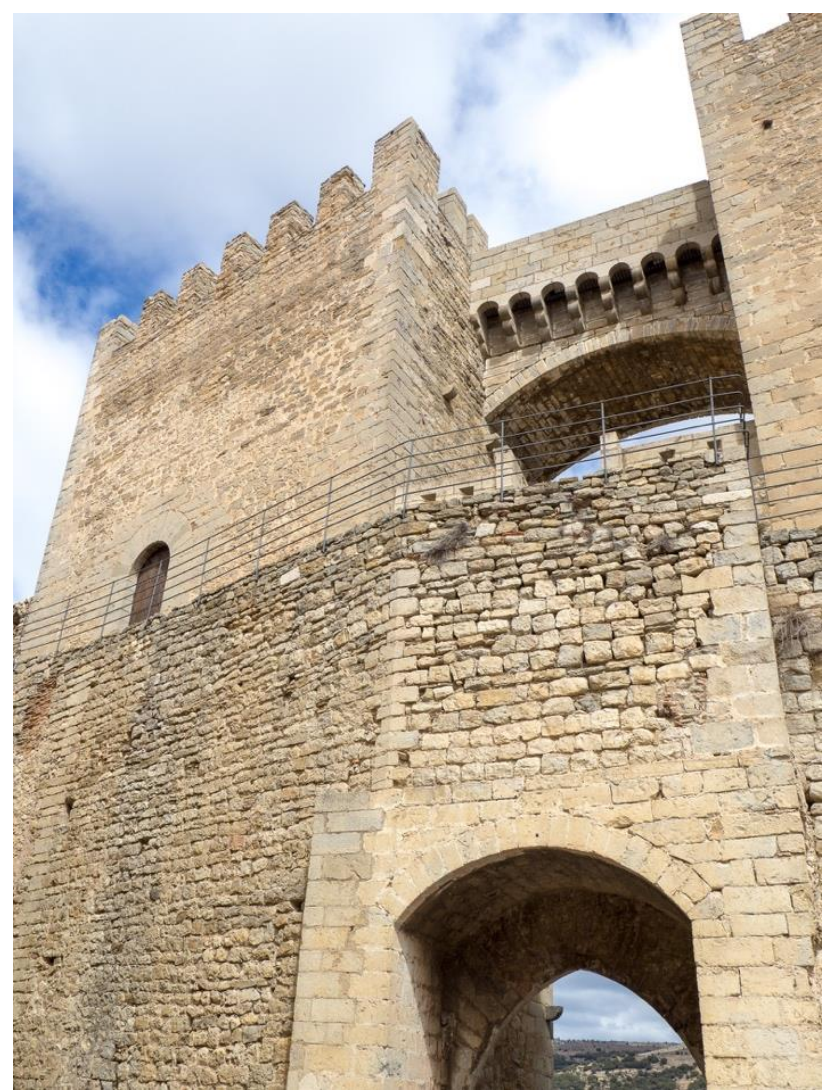

Figure 15. View of the Portal de Sant Miquel within city walls, the element of greatest architectural value in the walled ensemble (Source: S. Portela, 2018).

\section{REFERENCES}

Baker, N., 2011. Hereford city defences. A conservation Management Plan. Herefordshire Archaeology Report 292. Herefordshire Archaeology Environment, Planning \& Waste Herefordshire Council.

Collins, T., Darmody, N., O’Mahony, B., Lynch, L. G., Coyne, F., 2008. Limerick City Walls. Conservation \& Management Plan. Limerick City Council and the Heritage Council, Limerick.

Dalmases Balañà, N., Pitarch, A.J., 1983. Morella: Ciudad de Morella. In J. Bérchez (Ed.), Catálogo de Monumentos y Conjuntos de la Comunidad Valenciana. Conselleria de Cultura, Educació i Ciència, València.

Dualde Viñeta, V., 2016. Puertas y torres de Morella. Ajuntament de Morella, Morella.

Gallego Roca, F. J., 1996. La ciudad y sus murallas: Conservación y Restauración. Universidad de Granada, Granada.

Gowen, M., Simpson, L., McGarry, Ch., Edden, L., Carrig, Sh., Consarc, U., 2004. Conservation Plan Dublin city walls and defences. Dublin City Council, Dublin.

Gowen, M., Burridge, K., Edden, L., Consarc, U. Carrig, Sh., Mathews, P., Bradley, J., 2006. Conservation plan. Town walls and other defences of Drogheda. Drogheda Borough Council and The Heritage Council, Drogheda.

Grau i Montserrat, M., 1986. Los monumentos góticos civiles: Els Ports de Morella. Generalitat Valenciana, Conselleria de Cultura, Educació i Ciència, València.

Ham, S., 1992. Interpretación ambiental. Una guía práctica para gente con grandes ideas y presupuestos pequeños. North American Press, Golden.

Hernández Díaz, A., 1996. La conservación de las murallas de Ávila. In Gallego Roca, F. J. (Ed.), La ciudad y sus murallas. Universidad de Granada, Granada.

Instituto del Patrimonio Cultural de España, 2018. Plan Director de las Murallas de Ávila. Ministerio de Educación, Cultura y Deporte de España, Madrid.

Lacuesta Contreras, R., 1996. Jeroni Martorell y la restauración de murallas en Cataluña. In Gallego Roca, F. J. (Ed), La ciudad y sus murallas. Universidad de Granada, Granada.

Portela i Valls, S., 2019. Accions per a la posada en valor del patrimoni defensiu de Morella: Passeig interpretatiu per les muralles. Master's Degree Thesis. Universitat Politècnica de València, Valencia.

Taberner, F. (Coor.), 2010. Guía de Arquitectura de Valencia. Colegio Territorial de Valencia, València. 